\title{
In vitro Test for Inhibition of Plasmodium falciparum 3D7 Parasites using Streptomyces hygroscopicus subsp. hygroscopicus Strain i18, Isolated from a Pineapple Farm in Lampung
}

\author{
Endah Setyaningrum ${ }^{1}$, Achmad Arifiyanto ${ }^{1 *}$ (D), Nismah Nukmal ${ }^{1}$, \\ Titik Nur Aeny ${ }^{2}$ D, Meishy Handerlin Putri ${ }^{1}$ and Ulin Ni'mah Setiawati ${ }^{1}$ \\ ${ }^{1}$ Department of Biology, Faculty of Mathematics and Natural Sciences, Universitas Lampung, Indonesia. \\ ${ }^{2}$ Department of Plant Protection, Faculty of Agriculture, Universitas Lampung. Jl. Prof. Soemantri Brojonegoro \\ No 1, Gedong Meneng, Rajabasa, Bandarlampung 35144, Lampung, Indonesia.
}

\begin{abstract}
Increasing natural ingredient awareness and utilization has created an increased demand for sources of natural medicinal ingredients, including sources of compound used to treat malaria. Streptomyces is a genus of prokaryote well recognized for its production of antibiotics and other pharmaceutically useful compound. This study aimed to assess the ability of unpurified fermentation metabolites to inhibit Plasmodium parasites. A strain of bacteria identified as Streptomyces hygroscopicus subsp. hygroscopicus strain i18 were isolated from pineapple fields in Lampung province, and was cultured and fermented on liquid synthetic Gause medium for 10 days. The supernatant was separated from the cells and extracted with ethyl acetate-methanol (1:1). Plasmodium falciparum 3D7 was used for antiplasmodial testing. Metabolites were tested qualitatively using a phytochemical approach. Saponins and triterpenoids were found to be present in the extract. Parasite inhibition as measured using probit analysis and yielded an IC ${ }_{50}$ value of $11.07 \mathrm{~g} . \mathrm{m} / \mathrm{L}$. These findings suggest further examinations of this extract (e.g. assessment of off-target effects) are warranted.
\end{abstract}

Keywords: antiparasitic, actinomycetes, antimalarial, parasite, microbes

*Correspondence: achmad.arifiyanto@fmipa.unila.ac.id; +62-721 704625

(Received: April 04, 2021; accepted: May 26, 2021)

Citation: Setyaningrum E, Arifiyanto A, Nukmal N, Aeny TN, Putri MH, Setiawati UN. In vitro Test for Inhibition of Plasmodium falciparum 3D7 Parasites using Streptomyces hygroscopicus subsp. hygroscopicus Strain i18, Isolated from a Pineapple Farm in Lampung. J Pure Appl Microbiol. 2021;15(2):891-896. doi: 10.22207/JPAM.15.2.45

(C) The Author(s) 2021. Open Access. This article is distributed under the terms of the Creative Commons Attribution 4.0 International License which permits unrestricted use, sharing, distribution, and reproduction in any medium, provided you give appropriate credit to the original author(s) and the source, provide a link to the Creative Commons license, and indicate if changes were made. 


\section{INTRODUCTION}

Malaria remains a significant medical challenge, particularly in tropical countries ${ }^{1}$. Plasmodium parasites are responsible for malaria, which is transmitted by the bite of female Anopheles mosquitoes ${ }^{2}$. Malaria is often found in tropical coastal and rainforest habitats. It is endemic to Lampung province with a high rate of incidence ${ }^{3,4}$. Therefore, better resources for malaria control are needed.

Malaria control using a variety of natural ingredients are now widely pursued ${ }^{5}$, due to increasing resistance to synthetic antimalarial drugs. Exploration for antimalarial natural products has not been limited to plants. Animals and microbes have also been assessed ${ }^{6}$. Streptomyces is one of many microbial genera that has long been known for its anti-parasitic and anti-pathogenic metabolites, including antimalarials ${ }^{7}$.

Streptomyces are Gram-positive bacteria found scattered across various habitats. These bacteria are capable of controlling pathogen populations and producing biosurfactants ${ }^{8}$. A previous study succeeded in isolating the bacteria Streptomyces hygroscopicus subsp. hygroscopicus $\mathrm{i}^{1} 8^{9}$. These bacteria were shown to inhibit the growth of pathogens that caused root and stem rot, namely Dickeya zeae.

Plasmodium development is inhibited by the same bacterial strains, according to previous reports ${ }^{10}$. Determining the lethal doses of distilled extracts has been the subject of many antiparasitic studies. Distillation-based purifications are expensive and time-consuming ${ }^{11}$. It is important to know whether a crude extract obtained from Streptomyces hygroscopicus subsp. hygroscopicus can inhibit Plasmodium parasites without purification. This study thus aimed to learn more about Plasmodium inhibition by unpurified Streptomyces hygroscopicus subsp. hygroscopicus strain i18 fermentation extract.

\section{MATERIALS AND METHODS \\ Cell culture and fermentation}

Bacteria were cultured in liquid Gause media (LGM) with an adjusted $\mathrm{pH}$ of $7.3^{12}$. LGM media consists of soluble starch $20.0 \mathrm{~g}, \mathrm{KNO}_{3} 1.0$ g, $\mathrm{NaCl} 0.5 \mathrm{~g}, \mathrm{MgSO}_{4} \times 7 \mathrm{H}_{2} \mathrm{O} 0.5 \mathrm{~g}, \mathrm{~K}_{2} \mathrm{HPO}_{4} 0.5$ g, $\mathrm{FeSO}_{4} \times 7 \mathrm{H}_{2} \mathrm{O} 10.0 \mathrm{mg}$, dissolved in $1000 \mathrm{~mL}$ distilled water. Culture supernatant for extraction was prepared by scaling up cultures. Initially, a $10 \mathrm{~mL}$ test tube of LGM was inoculated with a single loop inoculum. After $24 \mathrm{~h}$ incubation, the $10 \mathrm{~mL}$ starter culture was used to inoculate $90 \mathrm{~mL}$ of LGM. This culture was incubated at room temperature for 10 days. Supernatant was obtained by centrifuging the culture for $30 \mathrm{~min}$ at $6000 \mathrm{rpm}$. Crude supernatant was filtered through filter paper and extracted with a 1:1 methanolethyl acetate solvent mixture ${ }^{13}$. The solvent was then evaporated using a rotary evaporator, yielding a paste that was lyophilized to form a powder.

\section{Qualitative metabolites screening}

Secondary metabolites content was determined by analyzing samples of the powdered extract. Testing was performed using a previously described qualitative approach ${ }^{14}$. Phenols, alkaloids, flavonoids, saponins, triterpenoids, anthraquinone glycosides, and tannins were prominent among identified compounds.

\section{Infrared Spectroscopy}

Infrared (IR) spectra of the crude extract were obtained using an Agilent Cary 630 spectrometer. Infrared spectra with wave numbers ranging from 400 to $4000 \mathrm{~cm}^{-1}$ were obtained. Resolution was reported in two sizes per wave number.

\section{In vitro antiplasmodial testing procedure}

Antimalarial activity testing was performed in vitro ${ }^{15}$. This study used Plasmodium falciparum strain 3D7, which chloroquinesensitive. One mg of sample extract was diluted in $100 \mathrm{~mL}$ of DMSO (stock solution, concentration $1.000 \mathrm{mg} / \mathrm{mL}$ ). Serial dilution were made from the stock solution. In this study, synchronous parasites (ring stage) approximating $1 \%$ parasitemia were used. Fresh type O-positive human erythrocytes were used to maintain cultures, which were suspended at 4 percent hematocrit in complete medium ${ }^{16}$. Parasites were added to 96 -well plates using a high-throughput liquid handler. Two microliters of various dilutions of extract were then added. Final extract concentrations were 100, $10,1,0.1$, and $0.01 \mu \mathrm{g} / \mathrm{mL}$. Plates were incubated under controlled gas condition $\left(\mathrm{O}_{2} 5 \%, \mathrm{CO}_{2} 5 \%, \mathrm{~N}_{2}\right.$ $90 \%$ ). Plates were incubated for $48 \mathrm{~h}$ at $37^{\circ} \mathrm{C}$, then erythrocyte slides prepared using $20 \%$ Giemsa staining.

Data were analyzed by counting the number of infected erythrocytes per 1000 total 
erythrocytes microscopy. These data were used to calculate growth and inhibition percentages. The following formula was used to determine the growth percentage:

$$
\% \text { growth }=\% \text { parasitemia }-D_{0}
$$

Where $\mathrm{D}_{0}$ represents initial $1 \%$ parasitemia prior to incubation (\%)

Inhibition is expressed as a percentage, and calculated using the formula below;

Percent inhibition $=100 \%-((X u / X k) \times 100 \%$

\section{Description}

$\mathrm{Xu}=\%$ growth in the presence of extract $X k=\%$ growth in the negative absence of extract

Extract concentration that inhibited parasite growth by up to $50 \%\left(\mathrm{EC}_{50}\right)$, was calculated using the two formulae above. The inhibitory concentration $\left(\mathrm{IC}_{50}\right)$ was determined using probit analysis and inhibition percentage results.

\section{RESULTS}

Streptomyces is genus of soil bacteria known to produce numerous secondary metabolites with useful human applications. Saponin and triterpenoid class compounds are produced by Streptomyces hygroscopicus subsp.
Table 1. Screening of metabolites compound results

\begin{tabular}{lc}
\hline Test & Result \\
\hline Phenols & - \\
Alkaloids & - \\
Flavonoids & - \\
Saponins & + \\
Triterpenoids & + \\
Anthraquinone glycosides & + \\
Tannins & - \\
\hline
\end{tabular}

hygroscopicus i18. Table 1 presents the findings of our secondary metabolite survey.

Saponin and triterpene extracts from Streptomyces hygroscopicus subsp. hygroscopicus strain i18 inhibited Plasmodium parasite cells growth by up to 81.11 percent at $100 \mu \mathrm{g} / \mathrm{mL}$. Growth inhibition was achieved at concentrations of $10 \mu \mathrm{g} / \mathrm{mL}(57.63 \%, 1 \mu \mathrm{g} / \mathrm{mL}(31.78 \%), 0.1 \mu \mathrm{g} / \mathrm{mL}$ (23.82\%), and $0.01 \mu \mathrm{g} / \mathrm{mL}$ (8.91\%). Fig. 1 illustrates this data in a logarithmic format. Inhibition of the growth of Plasmodium parasite cells was dose dependent. The probit data found that a treatment dosage of $11.07 \mu \mathrm{g} / \mathrm{mL}$ could suppress population growth by $50 \%$ (Fig. 2).

The bandwidth at $3212.96 \mathrm{~cm}^{-1}$ observed by FTIR analysis (Fig 3 ) is postulated to be linked to intermolecular $\mathrm{H}$ bonds. $\mathrm{A}=\mathrm{C}-\mathrm{H}$ bond, which can be found in any organic compounds was observed at $3060.61 \mathrm{~cm}^{-1}$ in the spectrum. Carboxylate

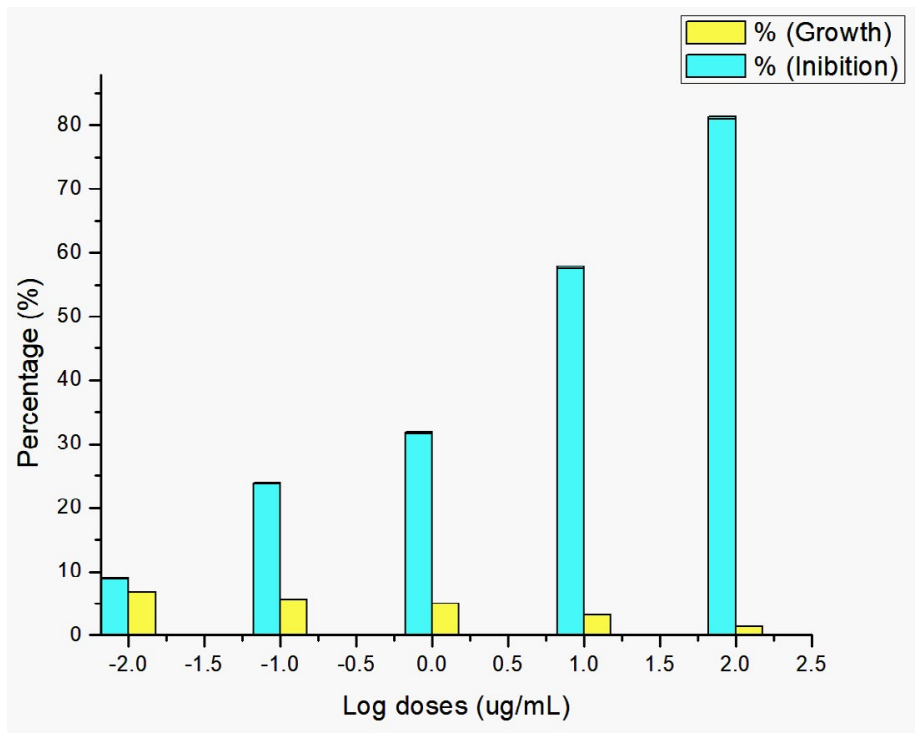

Fig. 1. The effect of giving bacterial extract on the growth of Plasmodium parasite. 
groups were present at $1424.23 \mathrm{~cm}^{-1}(\mathrm{CH} 2)$. At 990$1060 \mathrm{~cm}^{-1}$, a secondary cyclic alcohol appeared. At approximately 905-915 and 985-995, an alkene $(-\mathrm{CH}=\mathrm{CH} 2)$ was discovered in the bandwidth. Strain on the $\mathrm{C}-\mathrm{O}$ bond is indicated by the absorbance between 400 and $1250 \mathrm{~cm}^{-1}$.

\section{DISCUSSIONS}

Streptomyces bacteria are considered to be probiotic bacteria that offer a variety of health benefits. Member of this genus have long been known to produce antibiotics ${ }^{17}$ Antioxidants, pigment, and anticancer agents are

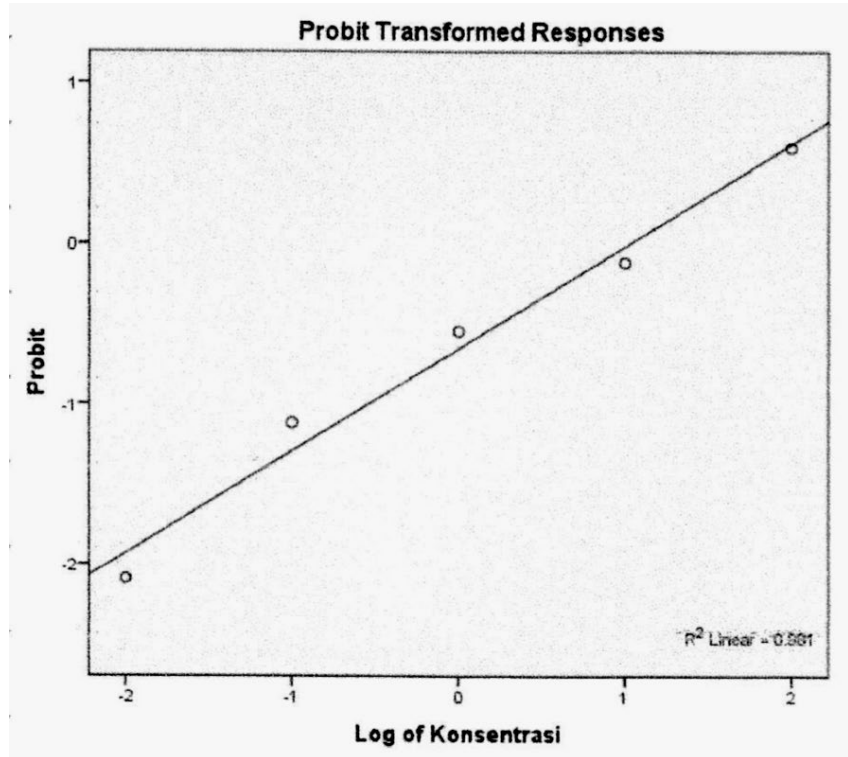

Fig. 2. Probit analysis of the inhibition of bacterial extract on the Plasmodium parasite.

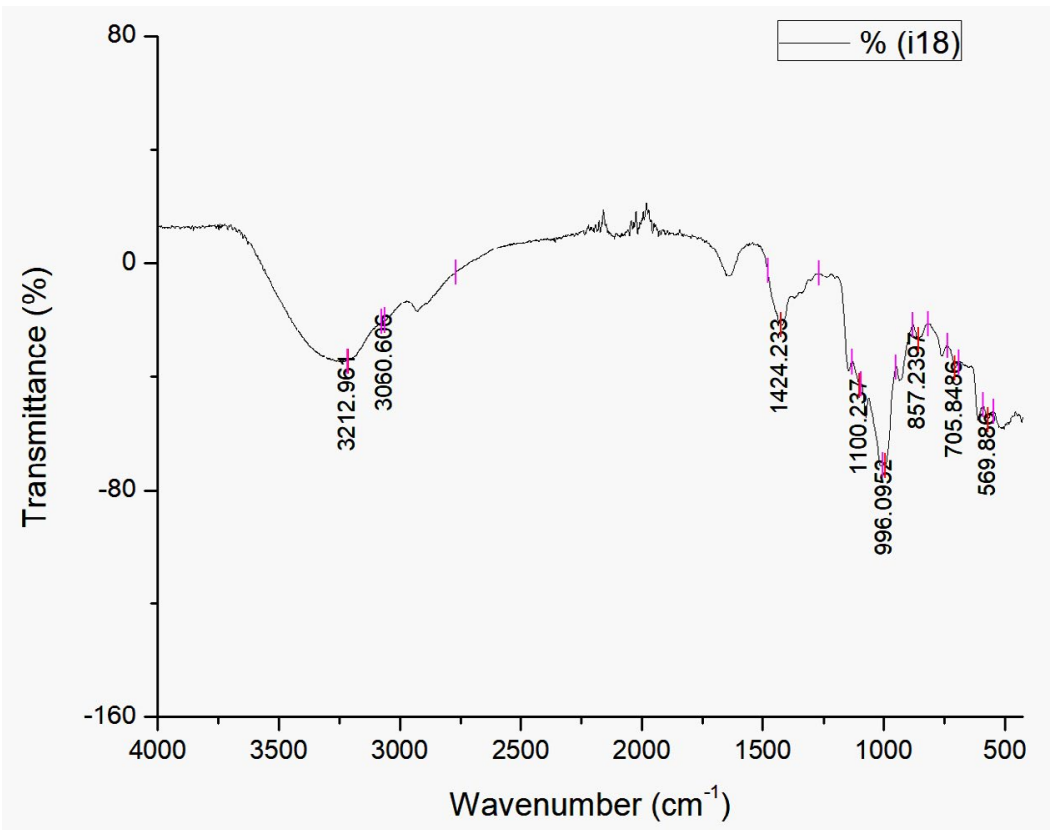

Fig. 3. Infrared spectroscopy using FTIR at biosurfactant produced by Streptomyces hygroscopicus subsp. hygroscopicus strain i18 fermentation extract

Journal of Pure and Applied Microbiology 
also produced by these bacteria ${ }^{18}$. The i18 strain produces saponins and triterpenoids, according to preliminary screening results for secondary metabolites (Table 1). Saponins have been described as having biosurfactant ${ }^{19}$. Biosurfactants can lower water's surface tension, disrupting the conformation of a target microorganism's cell membranes ${ }^{20}$. Saponins can produce emulsifying foam which can disrupt the stability of the hydrophobic core of phospholipid bilayers, causing micelles to form. Saponins have been shown to inhibit growth of pathogenic bacteria ${ }^{21}$.

Saponins and triterpenoids are closely related. Compounds in this group can be cyclic or non-cyclic, alcohol (OH), aldehyde, and carboxylic acid groups ${ }^{22}$. Spectroscopic analyses revealed the presence of a carboxylate group (Fig. 3). This carboxylate-containing isoform could be antidiabetic from a physiological standpoint. Some natural pigments are triterpenoids ${ }^{23}$. Triterpenoids dissolve readily in polar solvents, including water, owing to their composition. Geraniums' triterpene content has also been reported to be antibacterial ${ }^{24}$.

Since saponins in corporate glycosides in their structure ${ }^{25}$, the existence of anthraquinone glycosides in our Streptomyces exctract was not unexpected. This compound is structurally related to anthracene, but has a carbonyl group on each of the two atoms on opposite sides of the central ring. The color of this pigment ranges from yellow to orange. When ammonia is applied to anthraquinones, the majority develop a characteristic color reaction in Bontrager reagent tests ${ }^{26}$. In our extract, the solution became reddish, while the anthrone and dianthrone remained golden. Carboxyl groups are also present in anthraquinones, which can be extracted using alkaline media. Anthrones and anthranols (which reduce glycosides) are made from anthraquinones ${ }^{27}$.

The antimalarial compound gancidin was isolated from Streptomyces $\mathrm{sp}^{7}$. At doses of 6.25 and $3.125 \mu \mathrm{g} / \mathrm{kg}$, it can inhibit nearly $80 \%$ of malarial parasites. In these experiment purified gancidin was used. Unpurified extract from strain i18, displayed an inhibitory concentration of 11.07 $\mu \mathrm{g} / \mathrm{mL}$. The toxicity of a candidate compound has no bearing on its antiplasmodial efficacy. We did, however, consider the toxicity of non- antimalarial compounds. Despite high toxicity toward Plasmodium, the extract could poison non-target cells ${ }^{28}$. Because this was a preliminary investigation, the compounds used in this analysis were not purified. Further testing would be needed in the future due to the demand for pure compound that could be used for mechanistic and in vivo testing. Effect on metabolism and cell damage could explain any toxicities in human usage.

\section{CONCLUSIONS}

Preliminary studies were carried out using crude extract fermented by Streptomyces hygroscopicus subsp. hygroscopicus strain i18, which contained of saponins, triterpenoids, and anthraquinone glycosides. This crude extract displayed the potential to inhibit the growth of Plasmodium parasites. Its half maximal inhibitory concentration $\left(\mathrm{IC}_{50}\right)$ towards Plasmodium parasites was $11.07 \mu \mathrm{g} / \mathrm{mL}$. The results of this preliminary study need to be followed up with further research to establish physiological mechanisms and efficacy of pure compounds as antimalarial agents.

\section{ACKNOWLEDGMENTS}

We would like to express our gratitude to everyone who helped, supported and contributed to this research.

\section{CONFLICT OF INTEREST}

The authors declares that there is no conflict of interests.

\section{AUTHORS' CONTRIBUTION}

ES and AA did the conceptualization, approach, study, tools, evaluation, and editing of experimental results. NN and TNA drafted the manuscript and reviewed it. MHP and UNS performed the experiments.

\section{FUNDING}

This study was funded by Universitas Lampung in Indonesia (1509/UN26.21/PN/2020).

\section{DATA AVAILABILITY}

The datasets generated and/or analysed during the current study are available from the corresponding author on reasonable request. 


\section{ETHICS STATEMENT}

Not applicable.

\section{REFERENCES}

1. Laporta GZ, Prado PIKL de, Kraenkel RA, Coutinho RM, Sallum MAM. Biodiversity Can Help Prevent Malaria Outbreaks in Tropical Forests. PLoS Negl Trop Dis. 2013;7(3):e2139. doi:10.1371/journal.pntd.0002139

2. Cox FEG. History of the discovery of the malaria parasites and their vectors. Parasit Vectors. 2010;3:5. doi:10.1186/1756-3305-3-5

3. Elyazar IRF, Hay SI, Baird JK. Malaria distribution, prevalence, drug resistance and control in Indonesia. Adv Parasitol. 2011;74:41-175. doi:10.1016/B978-012-385897-9.00002-1

4. Rosa E, Shafira ID, Oktaria D, Arifiyanto A. Adherence to Plasmodium Vivax Malaria Treatment in Hanura Public Health Center, Pesawaran District of Indonesia.; 2020. doi:10.21203/rs.2.21806/v1

5. Tajuddeen N, Van Heerden FR. Antiplasmodial natural products: an update. Malar J. 2019;18:404. doi:10.1186/s12936-019-3026-1

6. Tse EG, Korsik M, Todd MH. The past, present and future of anti-malarial medicines. Malar J. 2019;18:93. doi:10.1186/s12936-019-2724-z

7. Ahmad SJ, Abdul Rahim MBH, Baharum SN, Baba MS, Zin NM. Discovery of Antimalarial Drugs from Streptomycetes Metabolites Using a Metabolomic Approach. J Trop Med. 2017;2017:2189814. doi:10.1155/2017/2189814

8. Arifiyanto A, Surtiningsih T, Ni'matuzahroh, Fatimah, Agustina D, Alami N. Antimicrobial activity of biosurfactants produced by actinomycetes isolated from rhizosphere of Sidoarjo mud region. Biocatal Agric Biotechnol. 2020;24:101513. doi:10.1016/j. bcab.2020.101513

9. Aeny TN, Prasetyo J, Suharjo R, Dirmawati SR, Efri, Niswati A. Short communication: Isolation and identification of actinomycetes potential as the antagonist of Dickeya zeae pineapple soft rot in Lampung, Indonesia. Biodiversitas. 2018;19(6):20522058. doi:10.13057/biodiv/d190610

10. Fitri LE, Alkarimah A, Cahyono AW, et al. Effect of Metabolite Extract of Streptomyces hygroscopicus subsp. hygroscopicus on Plasmodium falciparum 3D7 in Vitro. Iran J Parasitol. 2019;14(3):444-452.

11. Zhang Z, Tang W. Drug metabolism in drug discovery and development. Acta Pharm Sin B. 2018;8(5):721732. doi:10.1016/j.apsb.2018.04.003

12. Lin $Y B$, Wang $X Y$, Fang $H$, et al. Streptomyces shaanxiensis sp. nov., a blue pigment-producing Streptomycete from sewage irrigation soil. Int J Syst Evol Microbiol. 2012;62(8):1725-1730. doi:10.1099/ ijs.0.029959-0

13. Hage-Hülsmann J, Gru A, Thies S, et al. Natural biocide cocktails : Combinatorial antibiotic effects of prodigiosin and biosurfactants. PLOS One. 2018;13(7):e0200940. doi:10.1371/journal. pone. 0200940
14. Ezeonu CS, Ejikeme CM. Qualitative and Quantitative Determination of Phytochemical Contents of Indigenous Nigerian Softwoods. New J Sci. 2016;2016:5601327. doi:10.1155/2016/5601327

15. Sinha S, Sarma P, Sehgal R, Medhi B. Development in Assay Methods for in Vitro Antimalarial Drug Efficacy Testing: A Systematic Review. Front Pharmacol. 2017;8:754. doi:10.3389/fphar.2017.00754

16. Baniecki ML, Wirth DF, Clardy J. High-throughput Plasmodium falciparum growth assay for malaria drug discovery. Antimicrob Agents Chemother. 2007;51(2):716-723. doi:10.1128/AAC.01144-06

17. Fair RJ, Tor Y. Antibiotics and bacterial resistance in the 21st century. Perspect Medicin Chem. 2014;6:25-64. doi:10.4137/PMC.S14459

18. El-Naggar NEA, El-Ewasy SM. Bioproduction, characterization, anticancer and antioxidant activities of extracellular melanin pigment produced by newly isolated microbial cell factories Streptomyces glaucescens NEAE-H. Sci Rep. 2017;7:42129. doi:10.1038/srep42129

19. Mohammadi A, Sohrabi B, Rashidi M, Saeedi M. The extracted saponin from ginseng as an efficient renewable biosurfactant for desorption enhancement of phenanthrene and nickel. Int J Environ Sci Technol. 2019;16(1):181-190. doi:10.1007/s13762-017-1564-z

20. Karlapudi AP, Venkateswarulu TC, Tammineedi J, et al. Role of biosurfactants in bioremediation of oil pollution-a review. Petroleum. 2018;4(3):241-249. doi:10.1016/j.petlm.2018.03.007

21. Anestopoulos I, Kiousi DE, Klavaris A, et al. Surface active agents and their health-promoting properties: Molecules of multifunctional significance. Pharmaceutics. 2020;12(7):688. doi:10.3390/ pharmaceutics 12070688

22. Faizal A, Geelen D. Saponins and their role in biological processes in plants. Phytochem Rev. 2013;12(4):877893. doi:10.1007/s11101-013-9322-4

23. Salehi B, Ata A, V Anil Kumar N, et al. Antidiabetic Potential of Medicinal Plants and Their Active Components. Biomolecules. 2019;9(10):551. doi:10.3390/biom9100551

24. Rahmawati F, Bintang M, Artika IM. Antibacterial Activity and Phytochemical Analysis of Geranium homeanum Turez Leaves. 2017;4(3):13-22.

25. Podolak I, Galanty A, Sobolewska D. Saponins as cytotoxic agents: a review. Phytochem Rev. 2010;9(3):425-474. doi:10.1007/s11101-010-9183-z

26. Fabbrizzi L. The ferrocenium/ferrocene couple: a versatile redox switch. ChemTexts. 2020;6:22. doi:10.1007/s40828-020-00119-6

27. Derksen GCH. Red, redder, madder : analysis and isolation of anthraquinones from madder roots (Rubia tinctorum). 2001. https://library.wur.nl/WebQuery/ wurpubs/120750.

28. Flannery EL, Chatterjee AK, Winzeler EA. Antimalarial drug discovery - approaches and progress towards new medicines. Nat Rev Microbiol. 2013;11(12):849862. doi:10.1038/nrmicro3138 